\title{
ARTICLE \\ Contribution of Gulf of Aqaba Water (GAW) to Red Sea waters
}

\section{Mohideen Wafar*}

Center for Environment and Water, Research Institute, King Fahd University of Petroleum and Minerals, Dhahran 31261, Kingdom of Saudi Arabia

\section{ARTICLE INFO}

Article history

Received: 14 December 2020

Accepted: 4 January 2021

Published Online: 31 January 2021

\section{Keywords:}

Hydrography

Currents

Red Sea

Gulf of Aqaba

Red Sea Overflow Water

Gulf of Aqaba Water

\begin{abstract}
Data obtained on hydrography and currents in meridional sections in the Gulf of Aqaba and the Red Sea in November 2013 and March 2015 were used to determine the extent of contribution of Gulf of Aqaba Water (GAW) to the formation of Red Sea waters. The southward flow across the Strait of Tiran was $\sim 0.02 \mathrm{~Sv}$ in both periods which is direct evidence of significant contribution of GAW to Red Sea waters in autumn-winter. A multiple tracer analysis using temperature, salinity, and dissolved oxygen showed that the GAW, on entry into Red Sea, bifurcates into two branches. The upper branch exiting the Strait in the depth range 150-220 $\mathrm{m}$ has densities between 28.3 and 28.5, continues to flow at the same depths, and feeds the Red Sea Overflow Water (RSOW). The lower branch that exits between 220 and $250 \mathrm{~m}$ above the sill cascades down its southern face, mixes with northward recirculating branch of Red Sea Deep Water (RSDW) and sinks to the bottom and forms part of southward-flowing RSDW. Contribution of GAW to northern Red Sea waters below $100 \mathrm{~m}$ depth was $36 \pm 0.4 \%$ in November 2013 and $42.1 \pm 5.4 \%$ in March 2015. GAW is traceable down to $17-19^{\circ} \mathrm{N}$ in RSDW and RSOW. Volume contribution of GAW to RSOW was $9.6 * 10^{12} \mathrm{~m}^{3}$, about $50 \%$ higher than that for RSDW $\left(6 * 10^{12} \mathrm{~m}^{3}\right)$. Analyses of the data from R.V. Maurice Ewing cruise in 2001 gave similar results and lend support for these deductions.
\end{abstract}

waters are outflow of dense Gulf of Suez Water (GSW) ${ }^{[1-2]}$ and overflow of dense Gulf of Aqaba Water (GAW) ${ }^{[3]}$. Convective mixing in the extreme northern Red Sea ${ }^{[4]}$, horizontally widespread vertical mixing between deep water and the pycnocline ${ }^{[5]}$, non-convective injection of new deep water isopycnally just beneath the pycnocline ${ }^{[6]}$ are other potential sources, especially for RSOW.

The RSDW which fills the basin from about $200 \mathrm{~m}$ to the bottom is believed to be mainly formed in the Gulf of Suez area ${ }^{[1,4]}$ and has temperature/salinity characteristics

*Corresponding Author:

Mohideen Wafar,

Center for Environment and Water, Research Institute, King Fahd University of Petroleum and Minerals, Dhahran 31261, Kingdom of Saudi Arabia;

E-mail:mwafar@gmail.com. 
very similar to the RSOW ${ }^{[7]}$, but is distinguishable by its very low dissolved oxygen concentration ${ }^{[2,8]}$. However, the pattern of distribution of dissolved oxygen along the axis of the Red Sea observed in the 2013 section in the present study, and earlier in the 2001 section of R.V. Maurice Ewing cruise ${ }^{[7]}$, does not show a continuous decrease towards the bottom but an increase below $800 \mathrm{~m}$, to values greater than $100 \mu \mathrm{mol} / \mathrm{L}$ south of Strait of Tiran down to $24^{\circ} \mathrm{N}$. As the dissolved oxygen concentrations in the intermediate layers are less than $100 \mu \mathrm{mol} / \mathrm{L}$ and as the Gulf of Aqaba waters behind the sill are well-oxygenated (see below), it then follows that the RSDW must derive a significant contribution from GAW. While the deep water of the Red Sea are renewed through sinking of dense water formed in the two Gulfs ${ }^{[8]}$, the relative importance of either is only a conjunction even now.

The purpose of this paper is to quantify this contribution and trace the extent of the presence of GAW within the Red Sea basin. The RSDW flows close to the bottom from the north to south in the basin, upwells at the southern end and flows back to north at shallower depths but below the RSOW ${ }^{[8]}$. The depth range of the RSOW in the northern Red Sea is between 100 and $200 \mathrm{~m}^{\left[{ }^{[9]}\right.}$. As the sill depth at the Strait of Tiran ${ }^{[10]}$ is only $252 \mathrm{~m}$, the GAW exiting the Gulf of Aqaba will have to mix with both these water masses, and the RSDW and RSOW flowing south, therefore, will carry fractions of GAW with them. These were examined by applying the multiple tracer analysis ${ }^{[1]}$ which is an inverse method that uses measurements of the concentrations of several tracers variables to find the mixture of source water types that best describes (in a weighted least squares sense) the composition of a given water sample. Examples of application of this technique to oceanic water masses can be found in ${ }^{[11-17]}$. While the practice is to use three or more tracers, and usually with three water masses, it is also possible to use this approach with three tracers and two water masses (Mercier, H., pers. comm.). The data on temperature, salinity and dissolved oxygen collected during two cruises of R.V. Aegaeo, in autumn of 2013 and winter-spring of 2015, along the axis of the Red Sea extending through the Gulf of Aqaba were thus subjected to this analysis in the present study.

\section{Material and Methods}

Figure 1 shows the location of the stations in the Red Sea and Gulf of Aqaba occupied during the two oceanographic cruises of R.V. Aegaeo in 2013 (6-30 November) and 2015 (9-21 March). Table 1 provides the co-ordinates of the stations sampled. Continuous records of potential temperature $\left(T_{p o t}\right)$, salinity, and dissolved oxygen were obtained from the surface to the bottom using a Sea-Bird
SBE-9 CTD. Sensors for these parameters had been calibrated before the beginning of the cruise at the Hellenic Center for Marine Research, Greece. A Shipboard Acoustic Doppler Current Profiler (SADCP) was used to obtain 10-min averaged data on directions and velocities of the currents at $20 \mathrm{~m}$ intervals down to $500 \mathrm{~m}$ while at stations. The data were not subjected to any tidal correction as the tidal current was relatively weak (maximum tidal range $<$ $50-60 \mathrm{~cm})$.

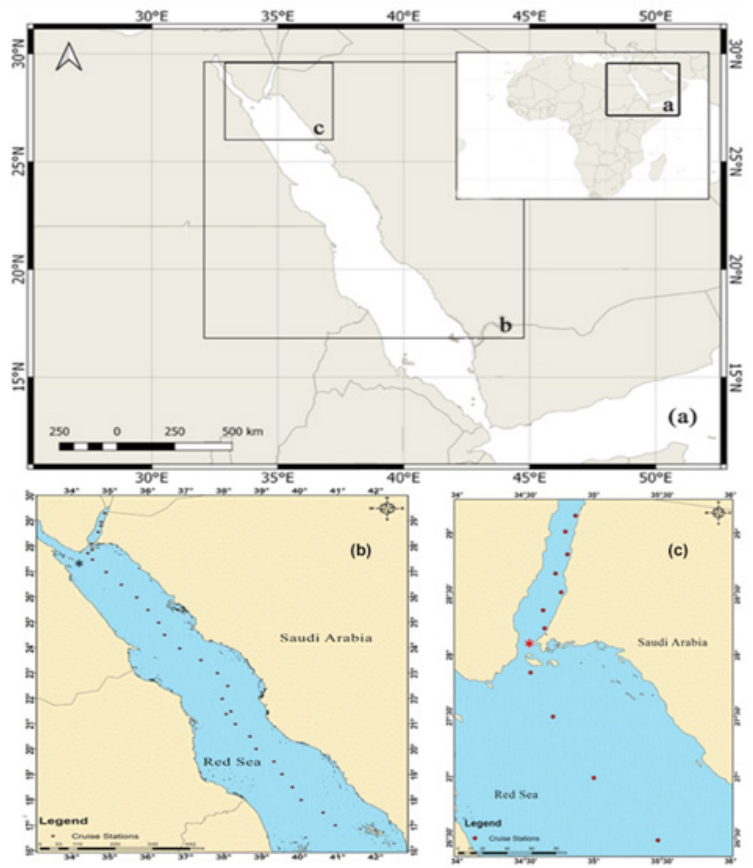

Figure 1. Location of study sites (a) and position of stations occupied in the Gulf of Aqaba and Red Sea in November 2013 (b) and March 2015(c)

Locations of the stations where core values for GAW (star in red) and RSDW and RSOW (star in black) were chosen are also shown.

Table 1. Co-ordinates of the stations occupied for this study

\begin{tabular}{ccc}
\hline Sea area & Lat ${ }^{\mathbf{N}}$ & Long ${ }^{\mathbf{E}}$ \\
Gulf of Aqaba & 28.55 & 34.7 \\
28.95 & 34.78 \\
29.3 & 34.87 \\
28.8 & 34.77 \\
29.14 & 34.86 \\
29.01 & 34.79 \\
28.83 & 34.81 \\
28.67 & 34.72 \\
28.52 & 34.76 \\
28.37 & 34.63 \\
\hline
\end{tabular}




\begin{tabular}{|c|c|c|}
\hline \multirow[t]{2}{*}{ Strait of Tiran } & 28.08 & 34.52 \\
\hline & 28.09 & 34.53 \\
\hline \multirow[t]{24}{*}{ Red Sea } & 27.85 & 34.53 \\
\hline & 27.48 & 34.53 \\
\hline & 27.47 & 34.55 \\
\hline & 27 & 34.91 \\
\hline & 26.48 & 35.31 \\
\hline & 26 & 35.71 \\
\hline & 25.5 & 36.01 \\
\hline & 25 & 36.29 \\
\hline & 24.5 & 36.45 \\
\hline & 24 & 36.85 \\
\hline & 23.5 & 37.4 \\
\hline & 23 & 37.84 \\
\hline & 22.5 & 38.11 \\
\hline & 22 & 37.96 \\
\hline & 21.5 & 38.19 \\
\hline & 21 & 38.31 \\
\hline & 20.5 & 38.69 \\
\hline & 20 & 38.85 \\
\hline & 19.5 & 39.32 \\
\hline & 19 & 39.53 \\
\hline & 18.5 & 39.81 \\
\hline & 18 & 40.04 \\
\hline & 17.5 & 40.53 \\
\hline & 17 & 40.88 \\
\hline
\end{tabular}

\section{Results}

Table 2 presents the characteristics of the source water types considered. For GAW in both the years, they were from two depths (175 and $225 \mathrm{~m}$ ) in profiles obtained at less than a km north of the Strait of Tiran $\left(28.08^{\circ} \mathrm{N}\right.$ and $28.09^{\circ} \mathrm{N}$ respectively). The depth over the peak of the sill at the Strait of Tiran is $252 \mathrm{~m}$ (Hall, 1975). For RSOW and RSDW, they were extracted from the profiles obtained at $27.41{ }^{\circ} \mathrm{N}$ and $34.06^{\circ} \mathrm{E}$ during the $R / V$ Maurice Ewing cruise to the Red Sea in 2001.

Plots of SADCP-derived directions at the Strait of Tiran $\left(28^{\circ} \mathrm{N}\right)$ showed that the flow (E/NE) into the Gulf of Aqaba occurs from surface down to $150 \mathrm{~m}$ and the flow (SW/W) into the Red Sea, at between 150 and $250 \mathrm{~m}$, during both the cruise periods (Figure 2). Calculations made with the averages of the current velocities obtained in the 150-250 m layer and the cross-section of $0.07 * 10^{6}$ $\mathrm{m}^{2}$ for the lower section of the Enterprise Channel ${ }^{[18]}$ gave a transport of $\sim 0.02 \mathrm{~Sv}$ in both instances.

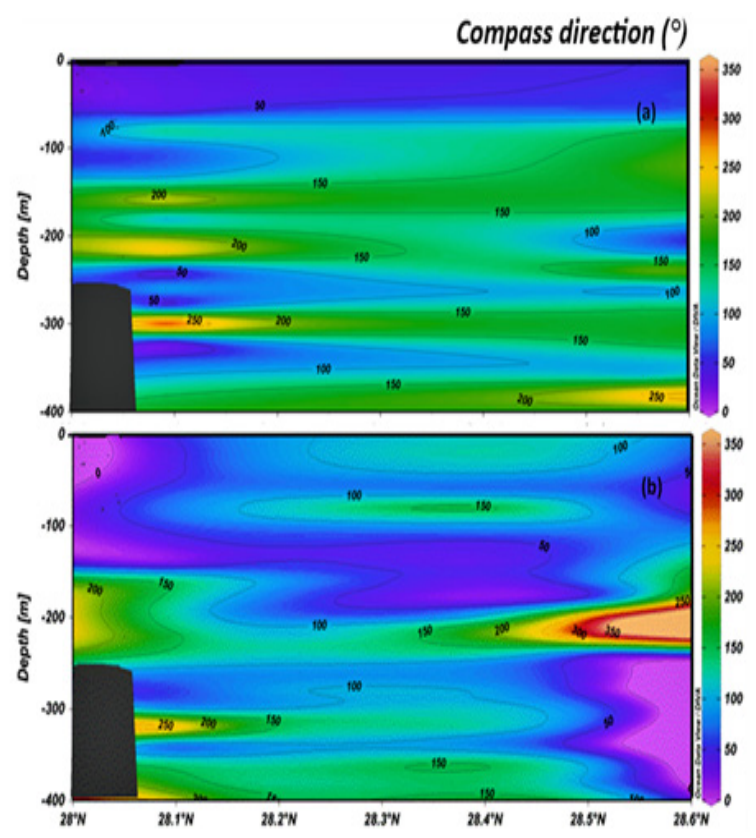

Figure 2. Directions of currents (in compass degrees) above the sill in the Strait of Tiran in (a) November 2013 and (b) March 2015

Table 2. Core values of properties of GAW, RSOW and RADW used for the multiple tracer analysis

\begin{tabular}{ccccc}
\hline Source water mass & Depth $(\mathbf{m})$ & $\mathbf{T}\left({ }^{\circ} \mathbf{C}\right)$ & Salinity & Dissolved oxygen $(\mu \mathrm{mol} / \mathbf{L})$ \\
\hline GAW (2013) & 175 & 22.91 & 40.58 & 183 \\
GAW (2013) & 225 & 22.07 & 40.67 & 185 \\
GAW (2015) & 175 & 21.72 & 40.56 & 192 \\
GAW (2015) & 225 & 21.69 & 40.58 & 141 \\
RSOW* & 175 & 22.1 & 40.54 & 77 \\
RSDW* & 540 & 21.57 & 40.57 &
\end{tabular}

Note: ${ }^{*}$ From R.V. Maurice Ewing cruise ${ }^{[7]}$ 
The distribution of temperature from the inner end of the Gulf of Aqaba $\left(29.3^{\circ} \mathrm{N}\right)$ to the southern limit of Saudi Arabian waters $\left(17^{\circ} \mathrm{N}\right)$ in the autumn of 2013 (Figure 3 ) was uniform below $200 \mathrm{~m}\left(22^{\circ} \mathrm{C}\right)$. Such was the case also with salinity (40.5-40.6) in the Red Sea but north of the sill at Strait of Tiran, in the Gulf of Aqaba, the waters were distinctly more saline ( 40.6 to 40.8 ). The distribution of dissolved oxygen was of a distinctly different pattern, with the minimum values ( 50 to $<25 \mu \mathrm{mol} / \mathrm{L}$ ) between 200 and $600 \mathrm{~m}$ in the Red Sea sandwiched between higher values: above $200 \mathrm{~m}$, the concentrations rose rapidly up to $150 \mu \mathrm{mol} / \mathrm{L}$ at $100 \mathrm{~m}$, just below the level of GAIW, and below $600 \mathrm{~m}$, they increased to $75-125 \mu \mathrm{mol} / \mathrm{L}$ in the north and 75-100 $\mu \mathrm{mol} / \mathrm{L}$ in the south. In the Gulf of Aqaba itself, the waters behind the sill were richer in dissolved oxygen $(200 \mu \mathrm{mol} / \mathrm{L}$ and above). What is important to note in these results is the continuity of salinity isolines 40.5 and 40.6 and dissolved oxygen isolines 150 and $175 \mu \mathrm{mol} / \mathrm{L}$ between the Gulf of Aqaba and the Red Sea over the sill depth. Taken together with the southward flow over a depth interval of $100 \mathrm{~m}$ (Figure 2 ), this is a clear demonstration of the flow of GAW into the Red Sea. This pattern can also be recognized in the data for 2015 (see below-Figures 6 and 7).
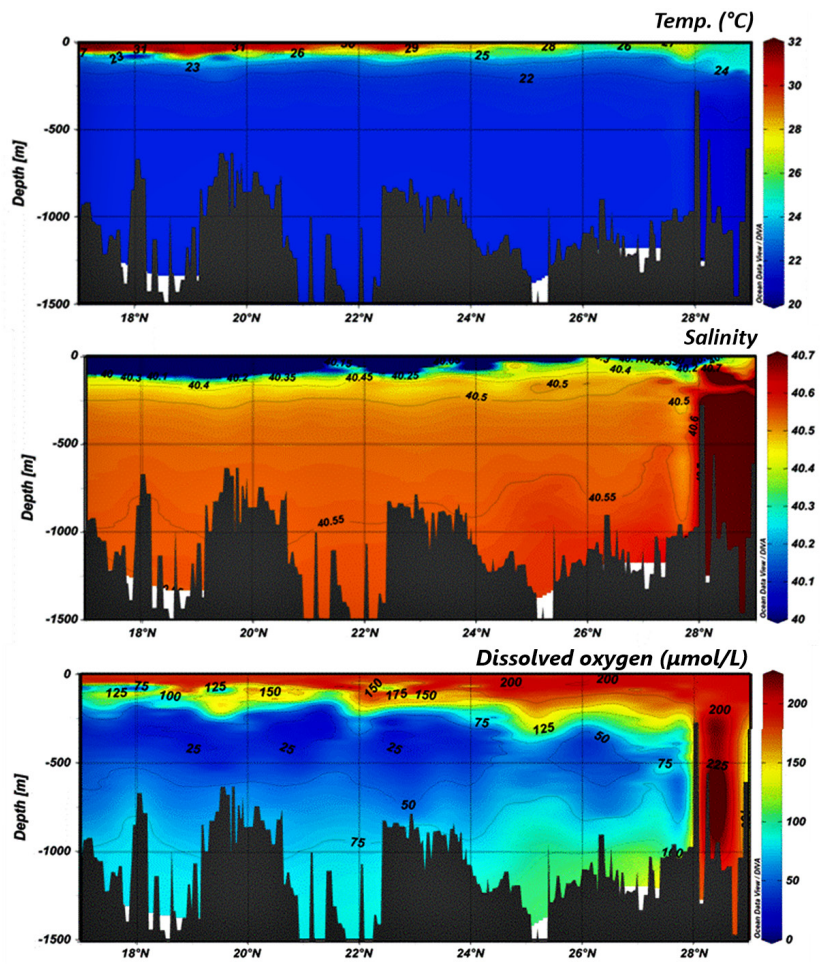

Figure 3. Sections of potential temperature, salinity and dissolved oxygen in the Gulf of Aqaba and the Red Sea in November 2013
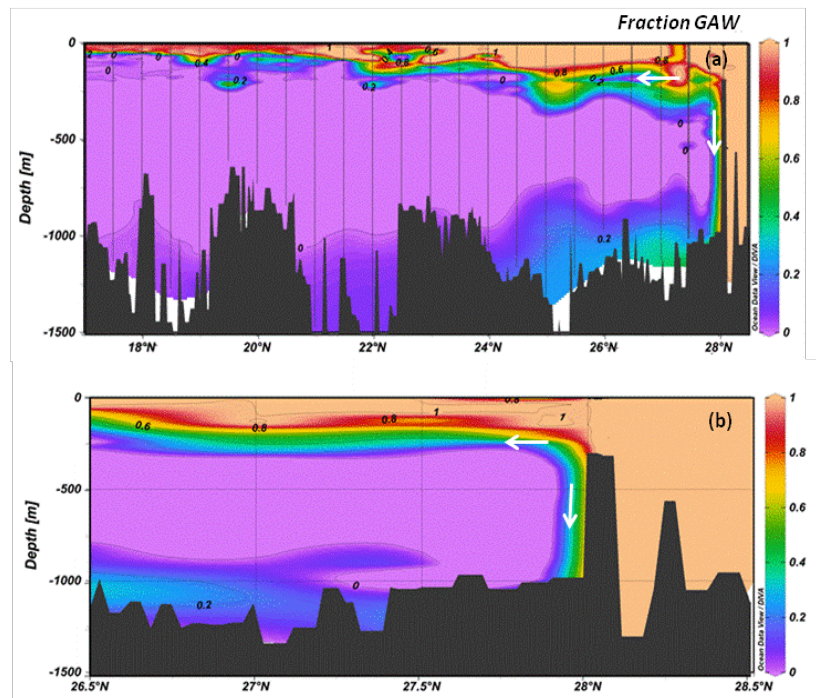

Figure 4. Fractions of GAW in waters in the Red Sea in (a) November 2013 and (b) March 2015. Arrows indicate the directions of the two branches of GAW

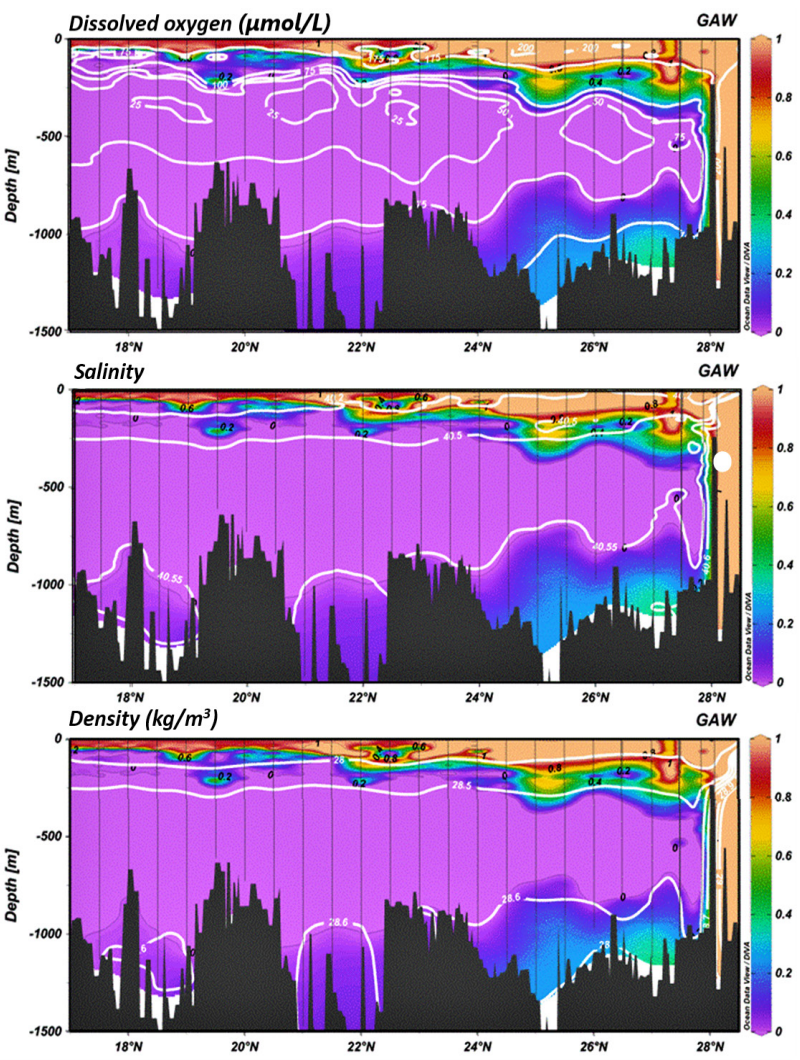

Figure 5. Distribution of fractions of GAW in November 2013 superimposed with those of dissolved oxygen, salinity and density

Decomposition of the hydrographic data into source water types showed clearly that the exit of GAW through the Strait of Tiran is accompanied by two major changes.

DOI: https://doi.org/10.36956/sms.v2i1.291 
The first is immediate mixing with the waters of the Red Sea and the second is division of this mixture into two branches south of the sill (Figure 4a). The upper branch, between 100 and $200 \mathrm{~m}$, where the fraction of the GAW varies rapidly from 0.1 to 0.9 , is characterized by a salinity of 40-40.5, dissolved oxygen content of 100-200 $\mu \mathrm{mol} / \mathrm{L}$ and a density of 27.7-28.5 (Figure 5). This can be detected down to $17^{\circ} \mathrm{N}$ but with a progressive reduction in thickness and decrease in GAW fraction. The lower branch cascades down the southern face of the sill towards the bottom and is characterized by a GAW fraction less than 0.3 , salinity $>40.55$, dissolved oxygen content of 75 $125 \mu \mathrm{mol} / \mathrm{L}$ and a density $>28.6$ (Figure 5). These waters can be traced close to bottom at depths greater than $900 \mathrm{~m}$, but with progressive decrease in the GAW fraction, also down to $17^{\circ} \mathrm{N}$ where the GAW fraction fully disappears. The deep waters in between these two branches do not show any presence of GAW.

The patterns of distribution of temperature, salinity and dissolved oxygen in March 2015 were similar to those of November 2013 (Figure 6): homogeneity from $200 \mathrm{~m}$ to bottom in the case of the former two in the Red Sea and Gulf of Aqaba, pronounced oxygen minimum between 300 and $900 \mathrm{~m}$ in the Red Sea, and well-oxygenated and more saline waters in the Gulf of Aqaba than in the Red Sea.
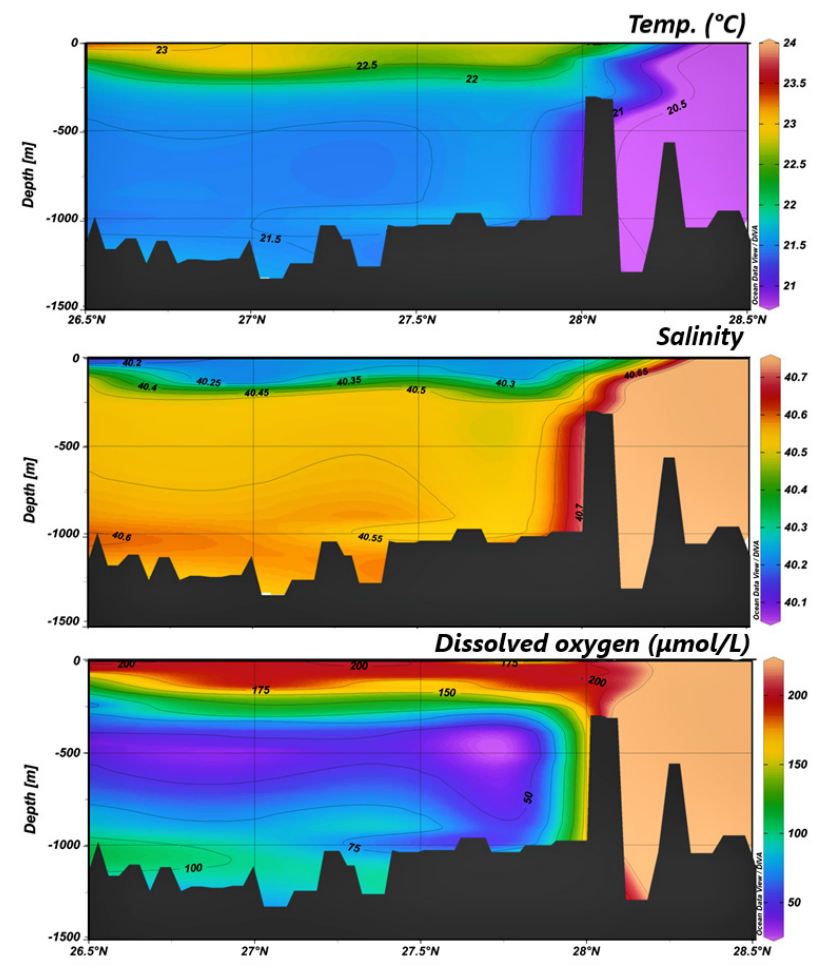

Figure 6. Sections of potential temperature, salinity and dissolved oxygen in the Gulf of Aqaba and the Red Sea in March 2015

Distributed under creative commons license 4.0
Presence of waters with more than $80 \%$ of GAW at between 150 and $250 \mathrm{~m}$ depth immediately south of the sill (Figure 4b), the continuity of salinity isolines 40.5-40.6 and those of dissolved oxygen $175 \mu \mathrm{mol} / \mathrm{L}$ above the sill between the Gulf of Aqaba and the Red Sea (Figure 6), and the direction of currents in Figure 2, taken together, are clearly indicative of flow of GAW into the Red Sea in March 2015. As was in 2013, the mixture with a significant fraction of GAW bifurcates into two branches but with slightly different characteristics (Figure 7). The lower branch has density $>28.6$ and its oxygen content was $>75$ $\mu \mathrm{mol} / \mathrm{L}$, increasing towards the bottom. The upper branch was slightly denser at 28.1 to 28.5 and more saline, with a salinity range of 40.3 to 40.5 , than in November 2013.

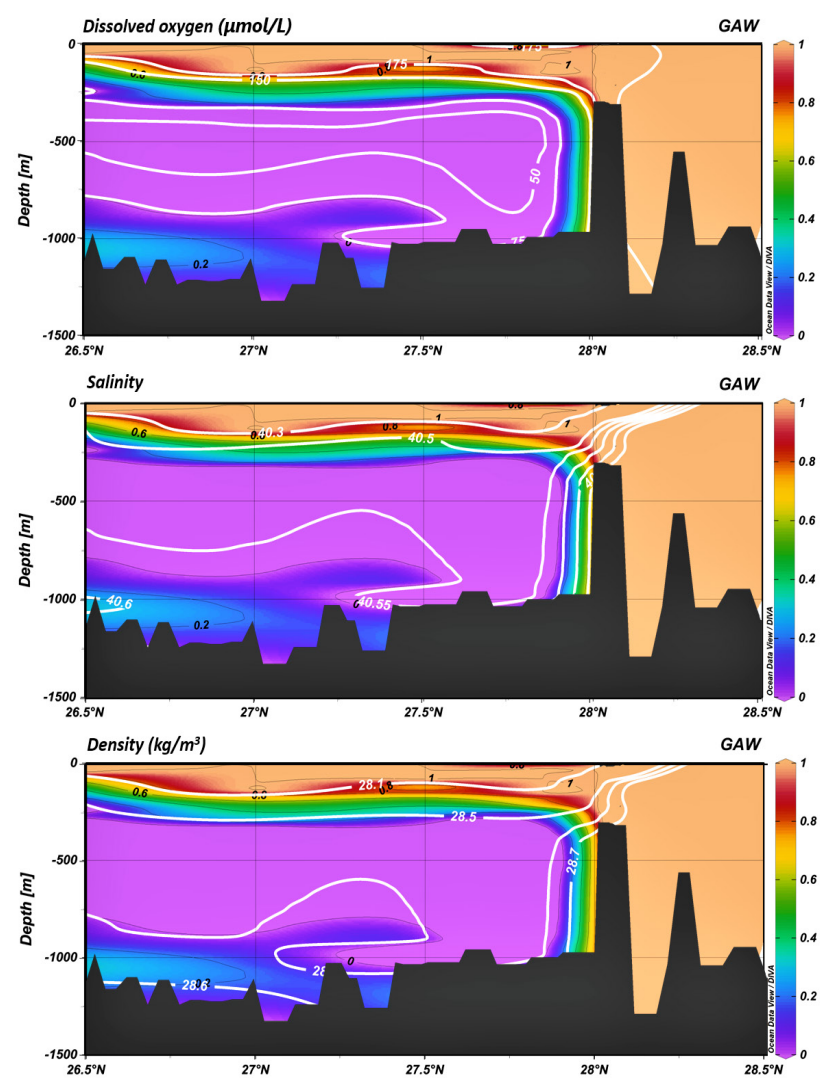

Figure 7. Distribution of fractions of GAW in March 2015 superimposed with those of dissolved oxygen, salinity and density

\section{Discussion}

\subsection{Data and Methodology}

The usefulness of these results can be best appreciated when viewed against the paucity of any such data in the past and the constraints of application of multiple tracer analysis. Because of geopolitical and security constraints, 
it was not possible earlier to establish sections from the Gulf of Aqaba through Strait of Tiran into the Red Sea. The only time when it could be done was during the $R /$ $V$ Meteor cruise in 1999 but sampling in that instance was limited to only few random stations in the extreme northern Red Sea (and none in Saudi waters) because of governmental restrictions ${ }^{[3]}$. Even during the $R / V$ Maurice Ewing cruise in 2001, there were no stations occupied near the Strait or across it. It was only in the R.V. Aegaeo cruises of 2013 and 2015 could full sections from the Gulf of Aqaba, across the strait and well into the Red Sea be established. This paucity of data also transcends to the number of tracers. The publication of Plähn et al ${ }^{[3]}$ based on the data collected during the $R / V$ Meteor cruise in 1999 , reported only temperature, salinity and chlorofluorocarbons.

Formation of dense waters in the Gulfs of Suez and Aqaba occurs in winter when intense evaporation and surface cooling take place ${ }^{[8]}$. In the case of Gulf of Suez, using hydrographic data and a model, Woelk and Quadfasel ${ }^{[2]}$ concluded that the deep-water formation happens only during winters with extreme forcing, and because of high temperatures in summer, the GSW cannot contribute to the formation of ventilated deep or bottom water in the Red Sea ${ }^{[3]}$. This is also the case with the Gulf of Aqaba where calculations by Klinker et al. ${ }^{[19]}$ and results of modeling by Biton and Gildor ${ }^{[20]}$ suggest that the summer outflow could only be between one-fourth and one-third of the winter outflow.

Under this situation, application of multiple tracer analysis for the data collected in autumn and winter is bestserved if the core values of the receiving water masses (RSDW and RSOW) are obtained in summer. Only the data from the $R / V$ Maurice Ewing cruise in summer of 2001 fit this requirement and hence have been used to obtain core values for RSOW and RSDW. It can be seen from Figures 5 and 7 that waters with densities between 28 and 28.5 exiting the Gulf of Aqaba continue to flow south in the 100-200 m depth range whereas those with higher densities sink immediately on exit. Therefore, data in the depth range of 0-250 m were processed with core values of GAW (175 m) and RSOW and those below, with core values of GAW (225 m) and RSDW, for estimation of the fractions of GAW which were then combined.

While the data collected during R.V. Aegaeo cruises included those on nutrients, which are often useful as tracers, as indeed evident from the marked differences in their concentrations on either side of the sill (unpublished data), data from $R / V$ Maurice Ewing cruise were limited to temperature, salinity and dissolved oxygen. Application of the multiple tracer technique was, therefore, limited to these three tracers, and as temperature and salinity varied within narrow limits (Table 1), deductions made depend mainly on the differences in dissolved oxygen contents. Changes in oxygen are brought about, besides mixing, also by biochemical consumption but the latter is confined mostly to shallower depths. This has been known from many studies, and even as far back as 1968, Menzel and Ryther ${ }^{[21]}$ showed that the oxygen content of Antarctic Intermediate Water in south Atlantic is independent of in situ decomposition of organic matter and that changes in its concentrations could be predicted by changes in salinity alone. Some contemporary studies where oxygen in water masses has been used as a tracer are those of Arhan et al. ${ }^{[22]}$ for deep waters and of You et al. ${ }^{[23]}$ and Ramesh et al. ${ }^{[24]}$ for Intermediate waters. Use of oxygen with data from RSDW depths is therefore justified and in fact, the gain in oxygen at depths greater than $800 \mathrm{~m}$ (Figures 3 and 6) could only be due to mixing (see below). Even at shallower depths, like those of RSOW, biochemical processes would alter the oxygen content in the GAW only to the same extent as would in the recipient water and hence the proportion of GAW in the mixture will still remain the same.

\subsection{Flow of GAW across Strait of Tiran}

It is known that GAW is a significant contributor to the deep waters of the Red Sea but most of the observed data were obtained only in winter. Use of hydrographic data ${ }^{[19,25]}$ and current meter data ${ }^{[18]}$ collected during this period gave southward flow rates in the saline lower layer across the Strait of Tiran as ranging from $\sim 29,000 \mathrm{~m}^{3} \mathrm{sec}^{-1}$ to $\sim 70,000 \mathrm{~m}^{3} \mathrm{sec}^{-1}$. Manasrah et al. ${ }^{[26]}$ noted similarities between the hydrographic characteristics of the wellmixed upper $450 \mathrm{~m}$ of the water in the Gulf of Aqaba and the northern Red Sea in winter and concluded that the former contributes significantly to deep water formation in the northern Red Sea. In a recent modeling study, Biton and Gildor ${ }^{[20]}$ predicted a potential for GAW flow across the Strait throughout the year, albeit at reduced intensities in non-winter months. The $\sim 0.02 \mathrm{~Sv}$ of flow for February calculated in this study is comparable to that $(0.029 \mathrm{~Sv})$ observed by Murray et al. ${ }^{[18]}$ and the 0.027 predicted by Biton and Gildor ${ }^{[20]}$. However, as was the case with Gulf of Suez ${ }^{[2]}$ or the Red Sea basin ${ }^{[27]}$, inter-annual variabilities in deep water formation in the Gulf of Aqaba may also have influences on the temporal changes in the contribution of GAW.

The results also bring direct evidence for a larger time window when contribution of GAW is significant. It has always been thought that waters cold enough and salty enough to form Red Sea deep water exist inside the 
Gulf of Aqaba only in winter ${ }^{[6]}$ which is relatively short, from January to March ${ }^{[28]}$. Thus, all earlier studies on the transport across the Strait of Tiran ${ }^{[18-19,25]}$ or assessment of contribution of GAW ${ }^{[3,26]}$ were limited to only winter (February-March). The present data provide direct evidence for contribution of GAW to Red Sea waters in autumn (Figures 4a and 5), with a contribution (36\%) only slightly less than that (42\%) in winter, thus extending the period of significant contribution of GAW to Red Sea waters by several months. Biton and Gildor ${ }^{[20]}$ deduced, from a modeling study, flow of GAW into the northern Red Sea throughout the year but with a strong seasonality. However, the flow calculated for November $(0.02 \mathrm{~Sv})$ is twice higher than that $(<0.01)$ predicted ${ }^{[20]}$. Understandably, more observational data will be needed to quantify precisely the temporal variations and annual contribution of GAW to Red Sea water masses.

\subsection{Fate of GAW in the Red Sea}

The GSW is a potential contributor to the south-flowing intermediate ${ }^{[29]}$ and deep ${ }^{[2]}$ waters in the Red Sea basin. However, the alignment of the Gulf of Suez basin with respect to that of Red Sea basin and the latitudinal range $\left(27.5\right.$ to $27.7^{\circ} \mathrm{N}$ ) (Figure 1) within which the flow of GSW into Red Sea could occur suggests unequivocally that over a distance of at least 50-60 km, or even more, in the northern Red Sea, it is only GAW that is the contributor to Red Sea waters below $100 \mathrm{~m}$. Summing up the fraction of GAW in the waters below $100 \mathrm{~m}$ depth in the three casts between $28{ }^{\circ} \mathrm{N}$ and $27^{\circ} \mathrm{N}$ and expressing it as a percentage of the total gave a contribution of $36 \pm 0.4 \%$ in November 2013 and $42.1 \pm 5.4 \%$ in March 2015 to waters in the northern Red Sea from where the southward flows commence. This is a substantial contribution, though falling short of the $60 \%$ calculated by Plähn et al. ${ }^{[3]}$ from a comparison of CFC signals measured in the waters of Gulf of Aqaba and at the bottom of the northern Red Sea. The fact that the percentages in this study were arrived at using a combination of classical tracers from several casts over a distance of $1{ }^{\circ} \mathrm{N}$ south of the sill, and the nearness between them in two different periods, suggests that an average contribution of $40 \%$ of GAW to the northern Red Sea waters would be a more realistic assessment. Until now, this was known only qualitatively, with adjectives ranging from modest to significant.

As was the case above, the GAW has been thought so far as a contributor to only deep waters of Red Sea-'Relatively small amounts of extremely dense water produced in the gulfs,.....sink to replenish the deep reservoir of the Red Sea ${ }^{\left[{ }^{8]}\right.}$. The results obtained here show a different picture. On crossing the Strait, the GAW bifurcates into two branches (Figure 4), with a lower branch traceable in waters close to bottom and the upper branch to intermediate waters, indicating contributions to both RSDW and to the layer ostensibly associated with RSOW.

\subsection{Contribution to RSDW}

Waters of GAW with densities greater than 28.5 at between 200 and $250 \mathrm{~m}$ depths (Figure 4) cataract down the southern face of the sill (Figure 5), mix with RSDW while sinking, and form a water mass of densities greater than 28.6 at the bottom. Comparing earlier only the oxygen profiles from a few stations near the sill in the two cruises, Papadopoulos et al. ${ }^{[30]}$ concluded that the dense water flowing out of the Gulf of Aqaba sinks piecing the layer of oxygen minimum (500-600) $\mathrm{m}$. The waters near the bottom bear, besides the signature of oxygen, also those of salinity and density of GAW. What is remarkable in Figure 5 is the close association of the 28.6 density and 40.55 salinity isolines with that of the $0.2 \mathrm{GAW}$ contribution line, suggesting that these waters propagate as a distinct entity of 100-200 m thickness above the bottom as far as $18-17^{\circ} \mathrm{N}$. The results also enable a quantification of contribution of GAW to freshly-formed RSDW. Summing up the fraction of GAW in RSDW (where deduced) at each station in the basin, an average contribution of 0.05 was arrived at for the latitudinal range from $28^{\circ} \mathrm{N}$ down to $17^{\circ} \mathrm{N}$, and to 0.04 for the whole of Red Sea. In terms of absolute volume, this translates to $6 * 10^{12} \mathrm{~m}^{3}$ of GAW in RSDW.

\subsection{Contribution to RSOW}

As far as RSOW is concerned, there are no direct observations available for its formation ${ }^{[8]}$. Model studies ${ }^{[31]}$ suggest that it is formed through open - ocean convection in the northern Red Sea, associated with a cyclonic gyre in that region, and flows southward below the surface layers ${ }^{[6,9]}$. As the RSDW fills the basin below about 250 $\mathrm{m}$ in the north ${ }^{[8]}$, the layer associated with the RSOW in the northern Red Sea is obviously in the 100-250 m depth range. It is into this layer that the upper branch of GAW leaving the Strait with densities between 28.1 and 28.5 flows (Figures 4, 5 and 7). Evidently, the GAW is also an important contributor to RSOW, with a GAW fraction of 0.85 at the origin of the RSOW layer immediately south of the sill (at $\left.27.85^{\circ} \mathrm{N}\right)$. This continues to decrease down to $<0.1$ by $21^{\circ} \mathrm{N}$ and to traces further south. The average contribution of GAW in the latitudinal range of $28^{\circ} \mathrm{N}$ to $17^{\circ} \mathrm{N}$ was 0.34 , which reduces further to 0.23 over the full length of the Red Sea. The volume contribution of GAW to RSOW was $9.6 * 10^{12} \mathrm{~m}^{3}$, about $50 \%$ higher than that 
for RSDW. Neither a contribution of GAW to intermediate layers (=RSOW) nor a level higher than that for RSDW have been contemplated in earlier studies.

The only other full hydrographic section of the Red Sea with 20 closely-spaced stations between $14.2^{\circ} \mathrm{N}$ and 27.5 ${ }^{\circ} \mathrm{N}$ was realized during the $R / V$ Maurice Ewing cruise in $2001{ }^{[7]}$ but in summer. The data from this cruise were made available and were subjected, in order to verify the reproducibility of the present results, to a similar multiple tracer analysis using the core values given in Table 1. The findings (Figure 8) are remarkably similar to those obtained with the data from R.V. Aegaeo cruises (Figure 4a and $4 \mathrm{~b}$ ) - presence of waters with significant fractions of GAW close to the bottom as far as $19^{\circ} \mathrm{N}$ and at depths of 100-250 m. The volume contributions of GAW calculated as above in this cruise in 2001 were $11.8 * 10^{12} \mathrm{~m}^{3}$ and 7.2 $* 10^{12} \mathrm{~m}^{3}$ respectively to RSOW and RSDW, about $20 \%$ higher than in 2013. What is remarkable in both sets of data is the similarity in the ratios of contributions of GAW to RSOW and to RSDW (1.61 in 2013 and 1.63 in 2001). These results thus strengthen the deductions made of the extents of contributions of GAW to intermediate and deep waters.

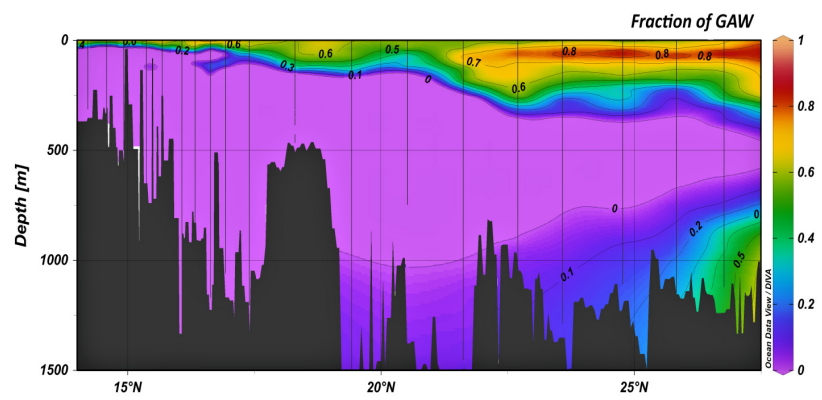

Figure 8. Fractions of GAW in waters in the Red Sea obtained from multiple tracer analysis of data from R.V. Maurice Ewing cruise in 2001

\subsection{Contribution of GSW}

Both GSW and GAW contribute to the formation of deep and intermediate waters of the Red Sea but assessing their relative importance has been constrained by the lack of synoptic observations and near-similarity in their hydrographic properties (ex. present data and those of ${ }^{[29]}$ ). However, the importance of GSW can be deduced, albeit, in an indirect way. The GSW that could contribute to deep waters in the Red has high salinities (>41) and densities $\geq 29^{[2-3]}$. So also is the GAW (Figure 5) where the 40.55 salinity isoline and 28.6 density isoline delimit the GAW contribution. Figure 9 shows the fractions of GAW calculated in the south-flowing RSDW layer. If the changes in them were to occur only by mixing with the waters of this limb of RSDW, then the data should align along a theoretical mixing line (the black line) from $27^{\circ} \mathrm{N}$ to $17^{\circ} \mathrm{N}$ where the GAW fraction is zero. The distribution of most data points, however, is negatively anomalous, with the largest region of anomaly lying between $25^{\circ} \mathrm{N}$ and $17^{\circ} \mathrm{N}$. This anomaly could presumably represent the contribution of GSW, the area of which is equivalent to a volume contribution of $1.68 * 10^{12} \mathrm{~m}^{3}$. The corresponding area for GAW (below the red line) was equivalent to a volume of $1.03 *$ $10^{12} \mathrm{~m}^{3}$, giving a GSW: GAW ratio of 1.63. Extending the northern limit to $27^{\circ} \mathrm{N}$ and re-analyzing the data gave a GSW: GAW ratio of 1.10 , suggesting that the contribution of GSW to Red Sea deep waters could lie between 1 and 2 times that of GAW. The extent of GSW to formation of RSOW is not known, but if the average fraction of GAW in RSOW (0.23) calculated from the data of 2013 cruise is any indication, then it could be up to 3 times higher than that of GAW. Thus, while the contribution of GSW could very well exceed that of GAW, resolving this further may become possible only when data on other tracers such as nutrients, or their conservative derivatives, such as NO and $\mathrm{PO}$, or even some other transient tracers, become available for GSW.

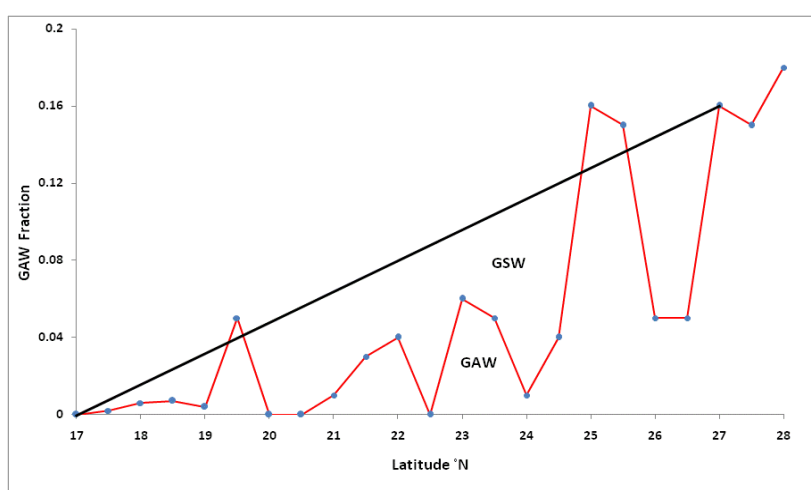

Figure 9. Fractions of GSW in south-flowing RSDW (red line). The black line represents the theoretical dilution line of GSW fractions in RSDW

\section{Acknowledgments}

The author is thankful to the Center for Environment and Water, Research Institute, King Fahd University of Petroleum and Minerals, Dhahran, Saudi Arabia, and Saudi Aramco, Dhahran for providing research facilities. Prof. Sofianos Sarantis, National and Kapodistrian University of Athens, kindly made available the data from R.V. Maurice Ewing cruise and the author is indebted to him. Helpful comments from Prof. Pierre Le Corre were useful in finalization of the manuscript.

\section{References}

DOI: https://doi.org/10.36956/sms.v2i1.291 
[1] Maillard, C. Eaux intermédiaires et formation d'eau profonde en Mer Rouge. L'océanographie physique de la Mer Rouge. Cent. Natl. pour l'Exploitation des Océans, Paris, 1974: 105-133.

[2] Woelk, S., Quadfasel, D. Renewal of deep water in the Red Sea during 1982-1987. J. Geophys. Res., 1996, 101, 18, 155-18,165.

[3] Plähn, O., Baschek, B., Badewien, B., Walter, T., Rhein, M. Importance of the Gulf of Aqaba for the formation of bottom water inthe Red Sea. J. Geophys. Res., 2002, 107, 22-1-22-18.

[4] Wyrtki, K. On the deep circulation of the Red Sea, in L'océanographie Physique de la MerRouge, 1974:135-163. CNEXO Publ. No.2.

[5] Kuntz, R. Bestimmung der Tiefenwasserzirkulation des RotenMeeresanhandeinerBoxmodellauswertung von Tritium, 3He- und Salinitatsdaten, Ph. D. thesis, RuprechtKarls Univ., 1985:76.

[6] Cember, R. P. On the sources, formation, and circulation of the Red Sea deep water, J. Geophys. Res., 1988, 93, 8175-8191.

[7] Sofianos, S. S., Johns, W. E. Observations of the summer Red Sea circulation. J. Geophys. Res, 2007, 112, C06025.

\section{DOI:10.1029/2006JC003886}

[8] Sofianos, S., Johns, W. E. Water Mass Formation, Overturning Circulation, and the Exchange of the Red Sea with the Adjacent Basins, in: N.M.A Rasul and I.C.F Stewart (eds.), The Red Sea, Springer Earth System Sciences, 2015.

\section{DOI:10.1007/978-3-662-45201-1 20}

[9] Zhai, P., Bower, A. S., Smethie, W. M. Jr., Pratt, L. J. Formation and spreading of Red Sea outflow water in the Red Sea. J. Geophys. Res., Oceans, 2015, 120, 6542-6563.

[10] Hall, J. K. Bathymetric chart of the Straits of Tiran, Isr. J. Earth. Sci., 1975, 24, 69-72. [11] Mackas, D.L., Denman, K.L., Bennett, A.F. Least squares multiple tracer analysis of water mass composition. J. Geophys. Res. C, 1987, 92, 29072918.

[12] Maamaatuaiahutapu, K., Garcon, V. C., Provost, C., Boulahdid, M., Bianchi, A. Spring and winter water-mass composition in the Brazil-Malvinas Confluence, J. Marine Res., 1994, 52, 397-426.

[13] Larqué, L., Maamaatuaiahutapu, K., Garcon, V. On the intermediate and deep water flows in the South Atlantic ocean, J. Geophys. Res., 1994, 102(6):12,425-12,440.

[14] You, Y. Seasonal variations of thermocline circulation and ventilation in the Indian ocean, J. Geophys. Res., 1997, 102(5):10+391-10+422.
[15] Goyet, C., Coatanoan, C., G. Eischeid, G., Amaoka, T., Okuda, K., Healy, R., Tsunogai, S. Spatial variation of total $\mathrm{CO} 2$ and total alkalinity in the northern Indian Ocean: A novel approach for the quantification of anthropogenic $\mathrm{CO} 2$ in seawater, J. Marine Res., 1999, 57: 135-163.

[16] Louarn, E., Morin, P. Antarctic Intermediate Water influence on Mediterranean Sea Water outflow. DeepSea Res., 2011, 58: 932-942.

[17] Wafar, M., Qurban, M. A., Ashraf, M., Manikandan, K.P., Flandez, A. V., Balala, A. C. Patterns of distribution of inorganic nutrients in Red Sea and their implications to primary production. J. Mar. Sys, 2016, 156: 86-98.

[18] Murray, S. P., Hecht, A., Babcock, A. On the mean flow in the Tiran Strait in winter, J. Mar. Res., 1984, 42: 265-287.

[19] Klinker, J., Reiss, Z., Kropach C. Levanon, I., Harpaz, H., Haliez, E. Observations on the circulation pattern in the Gulf of Elat (Aqaba), Red Sea, Israel J. Earth Sci., 1976, 25: 85-103.

[20] Biton, E., Gildor, H. The general circulation of the Gulf of Aqaba (Gulf of Eilat) revisited: The interplay between the exchange flow through the Straits of Tiran and surface fluxes. J. Geophys. Res., 2011, 116: C08020.

\section{DOI:10.1029/2010JC006860}

[21] Menzel, D. W., Ryther, J. H. Organic carbon and the oxygen minimum in the South Atlantic Ocean. DeepSea Res., 1968, 15: 327-337.

[22] Arhan. M., Mercier, H., Bourles, B, Gouriou, Y. Hydrographic sections across the Atlantic at $7 \cdot 30 \mathrm{~N}$ and 4"30S. Deep-Sea Res., 1998, 145: 829-872.

[23] You, Y., N. Suginohara, M. Fukasawa, H. Yoritaka, K. Mizuno, Y. Kashino, D. Hartoyo. Transport of North Pacific Intermediate Water across Japanese WOCE sections, J. Geophys. Res., 2003, 108(6): 3196.

\section{DOI:10.1029/2002JC001662}

[24] Ramesh, S., Ramadass, G. A., Ravichandran, M., Atmanand, M. A. Dissolved oxygen as a tracer for intermediate water mixing characteristics in the Indian Ocean. Curr. Sci., 2013, 105: 1724-1729.

[25] Anati, D. A. Water transports in the Gulf of Aqaba. L'Océanographie Physique de la Mer Rouge, 1974, 2: 165-173. CNEXO Publ.

[26] Manasrah, R., Badran, M., Lass, H. U., Fennel, W. Circulation and winter deep water formation in the northern Red Sea. Oceanologia, 2004, 46: 5-23.

[27] Yao, F., Hoteit, I. Rapid red sea deep water renewals caused by volcanic eruptions and the north Atlantic Oscillation. Science advances, 2018, 4(6): 5637. 
[28] Paldor, N., Anati, D. A. Seasonal changes of temperature and salinity in the Gulf of Elat (Aqaba). DeepSea Res., 1979, 26: 661-672.

[29] Sofianos S., Johns, W. E. The Summer Circulation in the Gulf of Suez and Its Influence in the Red Sea Thermohaline Circulation, J. Phys. Oceanogr, 2017. DOI:10.1175/JPO-D-16-0282.1

[30] Papadopoulos, V. P., et al. Factors governing the deep ventilation of the Red Sea. J. Geophys. Res., Oceans, 2015, 120(11): 7493-7505.

[31] Sofianos, S. S., Johns, W. E. An Oceanic General Circulation Model (OGCM) investigation of the Red Sea circulation: 1. Exchange between the Red Sea and the Indian Ocean. J. Geophys Res, 2002, 107(11): 3196.

DOI:10.1029/2001JC001184 